\title{
Value Added tax (VAT) - in View of Bangladesh
}

\author{
Rehana Ismail \\ PhD Research Fellow, Bangladesh University of Professionals
}

\begin{abstract}
This paper represents an overview of Value Added Tax (VAT) in Bangladesh. It depicts the basic features of Value Added Tax and its implication, and importance in the growing economy of Bangladesh. Bangladesh faces many problems in raising sufficient tax revenues to fund its economic and social development. To address this problem and to improve economic efficiency and growth, a major tax reform program was initiated in 1991 which centered on the introduction of a value-added tax (VAT) to replace a range of narrowlybased consumption taxes. This study works as a linkage between theory and practice on Value Added Tax. The article represents the social and economical development of the country with the basic awareness which is going at a steady pace among the people and the organization considering it as a key to further economical development. The awareness of Value Added Tax (VAT) is not very old, but still within a short span of time it has shown a remarkable change in the corporate sector and the economy of the country. It has developed a complete sense of care and responsibility towards the country and the welfare of the people.
\end{abstract}

Keywords: Value Added Tax, Social, Corporate, Economy, and Government.

\section{Introduction}

In the following pages of this article, the activities related to Value Added Tax in view of Bangladesh are discussed to define a clear picture regarding the basic awareness and development of VAT in Bangladesh. The basic objective of this article is to provide a basic understanding of VAT and its implications which results in the betterment of the people and the country. This study is based on the secondary work previously done by different government and private organizations, over a span of time as well as website information and other internal reports. The study was basically carried out through secondary information as well as discussions with the government officials. Before discussing the development, implications, and importance of VAT, an overview of VAT will be helpful to create a platform of understanding of the terms and concepts of VAT. ${ }^{[1]}$

A value added tax or value-added tax (VAT) is a form of consumption tax. From the perspective of the buyer, it is a tax on the purchase price, whereas, from the seller's point of view, it is a tax only on the "value added" to a product, material or service, at the stage of its manufacture or distribution. The manufacturer remits to the government the difference between these two amounts and retains the rest for themselves to offset the taxes they had previously paid on the inputs. The "value added" to a product by a business is the sale price charged to its customer, minus the cost of materials and other taxable inputs. A VAT is like a sales tax in that ultimately only the end consumer is taxed. It differs from the sales tax in that, with the latter, the tax is collected and remitted to the government only once, at the point of purchase by the end consumer.

With the VAT, collections, remittances to the government, and credits for taxes already paid occur each time a business in the supply chain purchases products. ${ }^{[1]}$ Personal end-consumers of products and services cannot recover VAT on purchases, but businesses are able to recover VAT (input tax) on the products and services that they buy in order to produce further goods or services that will be sold to yet another business in the supply chain or directly to a final consumer. In this way, the total tax levied at each stage in the economic chain of supply is a constant fraction of the value added by a business to its products, and most of the cost of collecting the tax is borne by business, rather than by the state. Value added taxes were introduced in part because they create stronger incentives to collect than a sales tax does. Both types of consumption tax create an incentive by end consumers to avoid or evade the tax, but the sales tax offers the buyer a mechanism to avoid or evade the tax - persuade the seller that he (the buyer) is not really an end consumer, and therefore the seller is not legally required to collect it. The burden of determining whether the buyer's motivation is to consume or re-sell is on the seller, but the seller has no direct economic incentive to collect it. The VAT approach gives sellers a direct financial stake in collecting the tax and eliminates the problematic decision by the seller about whether the buyer is or is not an end consumer. ${ }^{[1]}$

\section{An Overview of Value Added Tax}

A value-added tax (VAT) is a fee assessed against businesses at each step of the production and distribution process, usually whenever a product is resold or value is added to it. A VAT is levied on the difference between the purchase cost of an asset and the price at which it can be sold (i.e., the amount of value 
added to it). Producers and distributors typically pass the cost of the VAT on to the final consumer in the form of price increases. Tax is added to a product's price each time it changes hands until delivery to the customer takes place, when the final tax is paid. ${ }^{[13]}$ The value-added tax falls under the general category of a consumption tax, meaning taxes on what people buy rather than on their earnings, savings, or investments. VAT has also been referred to as a sort of national sales tax, though it functions very differently. Sales tax is imposed on the total retail price of the item sold, while VAT tax is imposed on the value added at each stage of production and distribution. And though more complicated than sales tax, value-added tax systems have more checks against tax fraud because the tax is assessed at more than one point in the distribution process. ${ }^{[13]}$

It is a percentage-wise tax on the value added to a commodity or service as each constituent stage of its production and distribution is completed. VAT may be classified in three ways: (i) on the basis of coverage of stages - throughout the production and distribution stages, or confined to limited stages - manufacturing plus wholesale, or wholesale plus retail; (ii) on the basis of the method of calculation - tax credit method, subtraction method, and addition method; and (iii) on the basis of tax treatment of final product capital goods such as machinery, equipment, and supplies - the consumption form, the income form, and the product variety. Thus the three broad types of VAT are the gross national product (GNP) type, income type, and consumption type. A consumption-type VAT is an indirect tax. An income type or a GNP type VAT might be considered as a direct tax but a commodity tax cannot be considered so. Consumption type VAT is also considered as an alternative form of 'sales tax'. ${ }^{[13]}$

\section{The Vat Assessment Process}

The process of assessing value-added tax occurs roughly as follows:

1. The manufacturer adds value to a product; the amount of value added can be described as the difference between the cost of the materials used to make the product and the price charged to the customer (often a wholesaler).

2. The manufacturer pays value-added tax (a percentage of the value added), which is then included in the purchase price charged to the customer (wholesaler).

3. The manufacturer gets a rebate from the government for VAT paid on the materials.

4. The customer (wholesaler) pays VAT on the value they add, which can be described as the difference between what they paid to the manufacturer and the price at which they sell it to their customer (retailer). This VAT amount is included in the price charged to the retailer.

5. The wholesaler gets a rebate for VAT from the government for the VAT paid to the manufacturer.

6. The retailer pays value-added tax on the value they add, which can be described as the price charged to customers less the wholesale cost and includes the VAT in the final sales price of the product.

The retail store collects value-added tax from the person buying the product (retail price thus includes all VATs collected at each stage of this process) and gets a rebate for the VAT paid to the wholesaler. ${ }^{[11]}$

\section{Basic Characteristics of Value Added Tax}

There are three types of value-added tax used around the world; each is different in the ways that taxes on investment (capital) expenditures are handled. The most common are the consumption method, which allows businesses to immediately deduct the full value of taxes paid on capital purchases. The second is the net income method, which allows gradual deduction of VAT paid on capital purchases over a number of years, much like depreciation. The third type, gross national product method of value-added tax, provides no allowance for taxes paid on capital purchases. The name of this type of tax is derived from the fact that the tax base is approximately equal to private GNP. The consumption method is most favored among general populations because it most equally taxes income from labor and capital and promotes capital formation. ${ }^{[15]}$

In theory, value-added tax systems with a uniform rate are neutral to all forms of productive input. However, countries across the world have had to modify the VAT system with multiple rates and exemptions to meet political, economic, and social needs. Most nations do not assess any tax on necessities such as food, medicine, and shelter. And because of the difficulty in computing value added tax, the professional services such as banking, accounting, and insurance are often exempt. The largest variation from uniform tax rates is the zero tax rates on exports. Since taxes will likely be assessed at a product's destination, many do not impose a tax on the final selling price of exports. To compensate, the VAT is applied to imported products. Hence, countries working together seek a more balanced trade. ${ }^{[15]}$ 


\section{Basis for VATs}

By the method of collection, VAT can be accounts-based or invoice-based. Under the invoice method of collection, each seller charges VAT rate on his output and passes the buyer a special invoice that indicates the amount of tax charged. Under the accounts based method, the tax is calculated on the value added, which is measured as a difference between revenues and allowable purchases. Most countries today use the invoice method, the only exception being Japan, which uses the accounts method. ${ }^{[16]}$ By the timing of collection, VAT (as well as accounting in general) can be either accrual or cash based. Cash basis accounting is a very simple form of accounting. When a payment is received for the sale of goods or services, a deposit is made, and the revenue is recorded as of the date of the receipt of funds - no matter when the sale had been made. Cheques are written when funds are available to pay bills, and the expense is recorded as of the cheque date-regardless of when the expense had been incurred. While accrual is more complex than cash basis accounting, it provides much more information about the business. The accrual basis allows to match revenues to the expenses incurred in earning them, giving one more meaningful financial reports. ${ }^{[16]}$

\section{VAT \& Its Necessity}

VAT is a multi-point tax system but without the effect of double taxation. Tax is chargeable at the rate prescribed at each point of sale. In Valued Added Taxation system, the tax is calculated at different points of production and distribution of a commodity. It is collected in installment on the basis of value added at each point of production and distribution. Since an input is taxed only once VAT avoids the cascading effect, which is the chief demerit of a generalized system of taxation i.e. excise and sales tax. ${ }^{[16]}$

There are several objectives associated with VAT, foremost being its revenue raising quality, due to the inclusion of items such as wages, interest, profits etc. in its base. It shall also bring in more discipline in the indirect tax regime. It is also imperative that VAT will take care of the demerits of the existing system. ${ }^{[16]}$

\section{Types of VAT}

The types of VAT are determined on the basis of treatment of capital goods of a firm. Input tax paid for capital goods is allowed or not is the fundamental question in the study of types of VAT. There are three types of VAT, they are:

- Consumption type

- Income type

- Gross National Product (GNP) type

1. Consumption Type VAT

Underconsumption type VAT, all capital goods purchased from other firms, in the year of purchase, are excluded from the tax base while depreciation is not deducted from the tax base in subsequent years. The base of tax is consumption since investment is relieved from taxation under this type. Consumption type VAT is widely used. Hence, by the term 'VAT' we basically mean the consumption-type VAT.

\section{Income Type VAT}

The income type VAT does not exclude capital goods purchased from other firms from the tax base in the year of purchase. This type, however, excludes depreciation from the tax base in subsequent years. The tax falls both on consumption and net investment. The tax base of this type is the net national income.

\section{GNP Type VAT}

Under this type, capital goods purchased by a firm from other firms are not deductible from the tax base in the year of purchase. It also does not allow the deduction of depreciation from the tax base in subsequent years. Tax is levied both on consumption and gross investment. The tax base of this type is a gross domestic product. ${ }^{[12]}$

\section{History of VAT}

The Joint Director of the French Tax Authority, named as Maurice Lauré, the Direction générale des impôts, was the first one to introduce VAT on April 10, 1954, although German industrialist Dr. Wilhelm von Siemens proposed the concept in 1918. Initially, VAT was directed at large businesses; it was extended over time to include all business sectors. ${ }^{[1]}$ Value-added tax was first suggested in Germany during the post-World War I period as a replacement for the country's turnover tax. The turnover tax was similar to the value-added tax system but did not provide rebates for the taxes paid at each stage. Other proponents of VAT suggested that the United States adopt it as a substitute for excise taxes imposed after the War. However, it was not until 1953 that the value-added tax system was put in place in the United States or Europe. That year, Michigan adopted a modified VAT, termed a Business Activities Tax, and used the system for 14 years. France was the first country to begin using value-added tax to partially replace its own turnover tax system. ${ }^{[3]}$ 
In 1967 the Council of European Economic Community (EEC) issued directives for widespread adoption of value-added tax to replace existing turnover taxes and link EEC members with a common tax system. The Council also hoped the new system would increase foreign trade, which was hindered by the complex regulatory practices of the turnover tax system. After the directive, countries outside the EEC such as Austria, Sweden, Brazil, Greece, and Peru also adopted some variation of the VAT, either in addition to or as a replacement for their own national tax structures. ${ }^{[5]}$

From 1987 to 1997, value-added tax was introduced in many eastern European countries, the former Soviet republics, and Asia. China, Thailand, the Philippines, and Bangladesh all implemented the policy during the mid-1990s. By the early 2000s, VAT had become a key component of the tax systems in more than 120 countries, with tax rates varying from 5 to 25 percent. Writer Liam Ebrill claimed in one of his article, "Finance and Development" that "the rapid rise of the value-added tax was the most dramatic and probably most important development in taxation in the latter part of the twentieth century, and it still continues." ${ }^{[5]}$ In April 1979, the Taxation Enquiry Commission (TEC) officially took up the issue of introducing VAT in Bangladesh as an alternative to sales tax. Until 1982, sales tax was being collected under the Sales Tax Act 1951, which was replaced by the Sales Tax Ordinance 1982 with effect from 1 July 1982. The World Bank played the pioneering role in the introduction of VAT in Bangladesh. A World Bank Mission visited Bangladesh for preparing an agenda for tax reform in Bangladesh in December 1986. The mission submitted its final report on 15 October 1989. The report recommended the introduction of a manufacturing-cum-import stage VAT at a single standard rate within three years. Thereafter, a Bangladesh Tax Mission visited India, Indonesia, the Philippines, and Thailand during 13 November - 04 December 1989. The Mission submitted its report in January 1990. The government discussed the issues relating to the introduction of VAT with all related private and public agencies including the various leading Chambers of Commerce and Industry from time to time. The government prepared the Value Added Tax Act 1990 (Draft) in June 1990. ${ }^{[10]}$

The final version of the Value Added Tax Act was promulgated on 31 May 1991 as a Presidential Ordinance with eight sections (relating to registration under VAT system and the appointment and powers of VAT authorities). It was made effective from 2 June 1991. The Value Added Tax Bill 1991 was introduced in the Parliament on 1 July 1991 and the Parliament passed it on 9 July 1991. With the Presidential assent to the bill on the next day, it came into effect as The Value Added Tax Act 1991. The VAT Act 1991 replaced the Business Turnover Tax Ordinance 1982 and the Sales Tax Ordinance 1982 with effect from 1 July 1991. In 1991-92, it imposed VAT @ 15\% on importer or supplier (producer) of taxable goods and provider of taxable services. The new law imposed VAT at zero-rate on export sales of any goods and services, brought excise duties on most goods under the VAT net, and imposed Supplementary Duty (SD) @ 10\% to 85\% on goods and services which are luxurious and non-essential and are socially undesirable. ${ }^{[10]}$

\section{National Board of Revenue (NBR): The Tax Central Collection Authority}

The National Board of Revenue (NBR) is the central authority for tax administration in Bangladesh. It was established by President's Order No. 76 of 1972. Administratively, it is under the Internal Resources Division (IRD) of the Ministry of Finance (MOF). MOF has 3 Divisions, headed by 3 permanent Secretaries to the Government, namely, the Finance Division the Internal Resources Division (IRD) and the Economic Relations Division (ERD). The Secretary of IRD acts as the Chairman of NBR. ${ }^{[16]}$ NBR is responsible for formulation and continuous re-appraisal of tax policies and tax laws, negotiating tax treaties with foreign governments and participating in inter-ministerial deliberations on economic issues having a bearing on fiscal policies and tax administration. The main responsibility of NBR is to collect domestic revenue primarily, Import Duties and Taxes, VAT and Income Tax for the government. Other responsibilities include administration of all matters related to taxes, duties and other revenue producing fees. Under the overall control of IRD, NBR administers the Excise, VAT, Customs and Income-Tax services consisting of a team of officers of various grades and supporting staff positions. ${ }^{[16]}$

National Board of Revenue (NBR) is the apex authority of the government responsible for collecting tax revenue, administering taxation administration and framing taxation policies and laws for the government. The main responsibility of NBR is to mobilize domestic resources through a collection of Import Duties, VAT, Excise and Income Tax for the Government. NBR through its different taxation sources collects more than 95\% of the tax revenue for the government. Four Members (top position of the hierarchy) of NBR from Direct Tax wing and four Members from Indirect taxation wing assist the chairman in executive, legislative and policy matters. ${ }^{[16]}$

\section{Objectives of Introducing Value Added Tax in Bangladesh}

The objectives behind introducing VAT in Bangladesh were to (a) bring transparency in the taxation system; (b) prohibit cascading taxation at different stages of production; (c) consolidate the tax administration; (d) activate the overall economy by mobilizing more internal resources; (e) bring a consistency in the tax-GDP 
ratio; (f) to bring neutrality of VAT which will not discriminate one economic activity against others. ${ }^{[20]}$ VAT introduced in Bangladesh in its initial form was a sort of consumption tax (by allowing the purchase of capital goods as input), which extended its coverage up to the level of import, production or manufacture, and servicerendering but not to export (which is zero-rated), wholesale or retail level. Since the financial year 1996-97, VAT in Bangladesh has become a broad-based consumption expenditure tax by covering the wholesale and retail levels. VAT is imposed on the following goods and services: all goods imported in Bangladesh except those mentioned in the First Schedule of the VAT Act; all goods supplied except those mentioned in the First Schedule of the VAT Act; and all services provided in Bangladesh except those mentioned in the Second Schedule of the VAT Act 1991.The standard tax rate for VAT has been fixed all along at $15 \%$ (for taxable goods and services). ${ }^{[20]}$

\section{Value Added Tax Features in Bangladesh}

The main features of VAT in Bangladesh are as follows:

1. VAT is imposed on goods and services at import stage, manufacturing, wholesale and retails levels;

2. A uniform VAT rate of 15 percent is applicable for both goods and services;

3. 15 percent VAT is applicable for all business or industrial units with an annual turnover of Taka 2 million and above;

4. Turnover tax at the rate of 4 percent is leviable where annual turnover is less than Taka 2 million;

5. VAT is applicable to all domestic products and services with some exemptions;

6. VAT is payable at the time of supply of goods and services;

7. Tax paid on inputs is creditable/adjustable against output tax;

8. Export is exempt;

9. Cottage industries (defined as a unit with an annual turnover of less than Taka 2 million and with a capital machinery valued up to Taka 3,00,000) are exempt from VAT;

10. Tax returns are to be submitted on monthly or quarterly or half yearly basis as notified by the Government.

11. Supplementary Duty (SD) is imposed at local and import stage under the VAT Act, 1991. ${ }^{[10]}$

\section{VAT Registration}

VAT registrations are compulsory for each location of a business. The taxable persons are to apply in a specific form to the VAT authority if their annual turnover exceeds 1.5 million taka. The taxpayers are given a registration number through a specific certificate. The registration certificate contains along with other information the activity codes in which the person is related. ${ }^{[10]}$ The registration numbers are used by the taxpayers in their business transactions. Registrations are done free of cost and are not subject to renewal. Any person whose annual turnover is less than 1.5 million taka or any person outside VAT may also apply for registration voluntarily. Any registration may be canceled if the person discontinues his business or if his annual turnover is found to be less than 1.5 million taka. ${ }^{[10]}$

Each taxpayer is required to issue a tax invoice, as proof of payment of VAT, for each supply of goods or services. However, the importers are not required to issue any tax invoice. But when importers sell their goods they may issue a supplementary tax invoice to a VAT registered person. VAT on imported goods is to be paid by the importers at the time when the customs duties on it are paid. In other words, VAT at import stage is paid before clearance of goods. But for the locally manufactured goods, VAT is payable at the time of supply of goods and services. Each registered supplier of goods or services is eligible to take instant credit of the VAT paid on inputs. The payments of VAT for goods (output tax) are made through adjustment in the account current book. ${ }^{[10]}$ Taxpayers are to keep sufficient balance to their credit in the current account book either through deposition of money to the Govt. treasury or through their input tax credit. Value added tax system in Bangladesh gives special treatment to the small firms. Under the system, small manufacturers and services whose annual turnover is less than 1.5 million taka is exempt from VAT but they are to pay turnover tax @ 2 per cent. Such turnover tax can be paid either at a time or on a quarterly basis. But they are not entitled to get credit benefit of their input taxes. ${ }^{[10]}$ Moreover, a small firm whose annual turnover is less than 1.5 million taka and whose investment in capital machineries only during a particular year does not exceed 300,000 taka are treated as a cottage industry and is fully exempt from VAT or turnover tax. They are also free from VAT formalities. It is easy to have the benefits of VAT in an economy where it is implemented in a comprehensive form covering all tiers of production and distribution as well as to all economic activities. ${ }^{[10]}$

\section{Self- Registration}

For producers or suppliers of vatable goods or services with annual turnover below Tk. 20 lacs, and for those within the scope of cottage industry, registration is not a lawful requirement. Even then some of them want to register, they can and this is called self- registration. The only advantage of registration, whether self or 
legally imposed, is that the registered producer, supplier or trader can adjust input tax against output tax which can have a significant role in pricing and selling the goods or services. ${ }^{[1]}$

\section{Requirement for Registration}

Application in form 'Mushak-6' shall have to be filed with concerned divisional VAT officer for registration, Name and address of the organization, taxpayers class, name of goods produced or procured, trade license No., TIN, if available IRC / ERC No. (where applicable) shall have $\mathrm{t}$ be mentioned in the application. Following documents shall be enclosed with the application:-

Trade License

TIN Certificate (if available)

IRC / ERC Certificate (where applicable)

List of all sale center when applied for central registration.

A declaration in form 'Mushak-7' regarding the place of production or purchase sale or stock of goods and its inputs. ${ }^{[11]}$

\section{Necessity of Registration}

When the annual turnover or sale of producer or trader of vatable goods or supplier of vatable services exceeds Tk. 20 lacs registration is a legal necessity. Turnover of any person, registered under the turnover tax when exceeds in any continuous 12 months Tk. 20 lac, he shall have to apply to the divisional VAT officer for registration within 30 days after the end of the tax period. In the case of a person carrying on his business where VAT has been newly imposed, he shall be required to be registered from the day of such imposition. ${ }^{[11]}$

The single stage VAT in Bangladesh has undoubtedly widened the tax base as compared to excise or sales tax system and has brought a favorable result in the collection of taxes but it had limited further results due to some limitation and distortion in its application. ${ }^{[1]}$

\section{VAT Administration}

VAT administration is one of the three wings of National Board of Revenue (NBR). Under the direct supervision and control of the Chairman NBR, Member (VAT) of NBR works as the head of operational and administrative activities of VAT administration. At present, there are eight VAT Commissionerates all over Bangladesh each headed by a Commissioner of VAT. ${ }^{[11]}$ Each VAT Commissionerates has five to eight divisions which are headed by Divisional Officers who may be Deputy Commissioners or Assistant Commissioners. Under each VAT Division, there are two to five circles which are headed by Superintendents. These circles are the basic building block of VAT administration. However, the head of each VAT division plays the most significant role for VAT collection and administration in the field level. ${ }^{[11]}$

\section{VAT Mechanism}

VAT system in Bangladesh operates under the legal framework of Value Added Tax Act 1991 and Value Added Tax Rules 1991 made under Value Added Tax Act 1991. As per VAT Act at a flat rate of $15 \%$ is chargeable on all goods and services imported in Bangladesh and on all goods and services produced in Bangladesh at every stage when the title of the goods and services of the concerned transaction is transferred. ${ }^{[1]}$

\section{Tax Expenditures in Bangladesh}

In recent years, the study of tax expenditures has gained increased importance in the literature of public policy, particularly in developing and transition economies. Such studies are primarily concerned with the reduction in tax liabilities resulting from various tax preferences such as preferential tax rates, exemptions, deductions, rebates, deferrals, credits, etc. These measures are often used as part of an efficient tax policy in order to achieve certain fiscal/social objectives, e.g., generating revenue at socially efficient and equitable level that minimizes its disincentive effects on economic activities, reducing pressure on public sector borrowing and substituting direct government expenditures (Cavalcanti and Li, 2000; Tanzi and Zee, 2000). These incentives may also be viewed as subsidy payments or government spending towards preferred taxpayers channeled through the existing tax system, besides direct expenditures of the government. Thus, it is necessary for a government to analyze tax expenditure accounting on a regular basis for maintaining efficiency, accountability and fiscal transparency of the country. ${ }^{[12]}$ Tax expenditure measures are tax provisions, liabilities or concessions that fall outside a benchmark tax system. Tax expenditures may take a variety of forms such as tax exemptions, deductions, exclusions, allowances, credits, deferrals, relief, etc (OECD, 1996 and WB, 2003). The establishment of an efficient and effective tax system by giving special attention to tax preferences plays an important role in a developing economy like Bangladesh, which faces constraints to requisite revenue generation due to lower domestic tax bases and increased integration with the world economy. The analysis of tax expenditure accounting is necessary broadly from two perspectives: first, it gives an indication about potential 
areas for further revenue generation; and second, it gives additional information about actual budget expenditures of the government that is not reflected in spending program of the budget documents. ${ }^{[12]}$ The tax system of Bangladesh includes several tax expenditure measures under the broad headings of direct taxes and indirect taxes. These provisions, introduced with the enactment of the tax law, have been subject to changes from time to time. The major policy objectives behind the tax expenditure measures in Bangladesh are to accelerate the process of industrialization, to attract foreign currency through increasing exports and foreign direct investment (FDI) and to ensure social security and welfare of low and modest income groups. Tax expenditure measures exist in sectors such as Public Services, Agriculture, Labor and Employment Affairs, Transport and Communication and Social Security and Welfare, etc. ${ }^{[12]}$

\section{Necessity of Tax Reform in Bangladesh}

The importance of the increase in domestic revenue is well recognized since the beginning of socioeconomic and infrastructural development in Bangladesh. Since more than 80 percent of total revenue comes from taxes, restructuring the tax system by introducing the VAT was thus critical. ${ }^{[17]}$ Bangladesh relies heavily on trade taxes. But studies of the tax structure of certain developing countries suggest that the economic cost of trade taxes is much higher than domestic consumption taxes. The trade taxes lead to the creation of inefficient domestic industries by penalizing exports. ${ }^{[17]}$ The tax structure (before introducing the VAT) was inelastic, unresponsive to the growth in overall economic activity. Taxes on agricultural income and property incomes are negligible and poorly administered. Therefore, in order to ensure self-reliant growth and reduce external dependence, the domestic resource mobilization efforts in Bangladesh have to be graded up. ${ }^{[14]}$ So to keep pace with the ever-growing public expenditure (which is required to meet public needs) and make the resources available for development efforts, there is no substitute for a comprehensive tax reform. Such a reform should aim at raising revenue as well as eliminating the tax-induced distortions in the structure of the economy. The introduction of the VAT is the centerpiece of this reform effort. ${ }^{[14]}$

\section{Value Added Tax on Goods \& Services}

The computation of actual value-addition requires detailed recording of payments for goods/services bought, which is not properly done in Bangladesh. To ease the administrative steps for taxation of services, in specified cases, a 'truncated value-base' was fixed with the option of waiving 'input tax credit'. Under the VAT system, tax points depend on the stage of production and distribution. For goods imported by any importer, VAT is to be paid at the time of paying import duty under the Customs Act $1969 .{ }^{[17]}$ For goods produced or manufactured or imported, purchased, acquired, or otherwise collected by any registered persons in the course of business operation or expansion, VAT is to be paid at the time of one of the following activities whichever occurs first: (a) when the goods are delivered or supplied; (b) when an invoice relating to the supply of goods is given; (c) when any goods are used personally or given for use to another person; and (d) when the price is received in part or full. For services rendered by any registered persons in the course of business operation or expansion, VAT is to be paid at the time of one of the following activities whichever occurs first: (a) when the services are rendered; (b) when an invoice relating to the rendering of service is given; and (c) when the price is received in part or full. For goods or class of goods for which the national board of revenue has ordered through the official Gazette notification to use stamp or banderole or special sign or mark having security system of specified value on package or carrier or container of the goods, VAT is to be considered as paid equivalent to the value of the stamp or banderole or special sign or mark used. ${ }^{[17]}$

Taxation remains a poor tool of government revenue collection in Bangladesh. The introduction of VAT contributed significantly to raise the tax revenue collection in Bangladesh. The share of VAT as a percent of different indicators (internal trade tax, external trade tax, indirect tax, total tax, total GDP, and nonagricultural GDP) has usually an increasing trend and the shares are significant. Thus almost the whole economy falls under the VAT-net and as a consumption tax, VAT is supposed to streamline the economic activities with corrective measures by applying supplementary duty. ${ }^{[17]}$

\section{Why the VAT is Preferred for Bangladesh}

The reasons for preferences of the VAT for Bangladesh are: it has more advantages than disadvantages compared to other taxes. Moreover, the tax structure prior to July 1991. In Bangladesh was highly defective. Tax evasion was widespread particularly among the rich. The tax structure was also discriminatory against export and biased towards inefficiency. The tax system was also inequitable and there were large scale allegation of corruption. ${ }^{[20]}$ Moreover, there was more than one rate in the tax system which would result in economic inefficiency and administrative complicacy. The cascading effect of the indirect taxes would increase the production costs, induce the producers to evade taxes and generate some problems which have been discussed earlier. It would also reduce the consumer's welfare through the price-rise. ${ }^{[11]}$ Therefore, due to 
intrinsic problems of the indirect tax system, revenue collection of the government was never satisfactory. To overcome this deficiency and to make the indirect tax system more dynamic and fruitful, the VAT has been introduced. ${ }^{[13]}$

\section{Advantages of Vat}

The introduction of VAT Concept was a spectacular fiscal phenomenon. Within a short period of time, this tax has exploded from its rudimentary form to become the state-of-the-art tax on goods and services all around the globe. Today the VAT has come to be acclaimed more and more as the most efficient, broad-based and revenue-productive system of indirect taxation. In recent times VAT has been increasingly adopted by many developing countries around the world that share with Bangladesh the same policy objectives of development and socio-economic stability and are subject to the same constraints that may affect the efficiency of the tax administration. The advantages of Value Added Tax are as follows: ${ }^{[9] ; ~[16] ~}$

1. Neutrality The greatest advantage of the system is that it does not interfere in the choice of decision for purchases. This is because the system has anti-cascading effect. The system is neutral with regard to choice of production techniques, as well as business organization. All other things remaining the same, the issue of tax liability does not vary the decision about the source of purchase.

2. Certainty and Transparency: The VAT is a system based simply on transactions. Thus there is no need to go through complicated definitions like sales, sales price, turnover of purchases and turnover of sales. The tax is also broad-based and applicable to all sales in business, thus there is little room for different interpretations. Similarly, due to the basic feature that it gives credit of tax paid on earlier stage, the buyer will always ask for invoice. Thus the scope of tax avoidance or evasion will be much less. The disputes will also be fewer. This system brings certainty to a great extent as the buyer knows, what tax component is. Thus, the system ensures transparency also.

3. In Widespread Use VAT is in use in well over sixty countries throughout the world. In its usual form, it is a transaction-based consumer tax applicable to both goods and services, with the invoice (on which the VAT liability may be shown separately) acting as the basic evidential document. It is neutral in effect, the tax liability on sales (outputs) being offset by the tax paid on purchases (inputs). It thus avoids "cascading"; tax being paid again on goods which have already borne tax, which frequently occurs in the case of general sales taxes.

4. Harmonized System of Taxation: Vat became popular because of its built-in advantage of harmonizing the tax structure. It leaves very small room for interpretation. Ideally under VAT, there should be only one basic rate. In any case, typically, VAT involves lowering the number of tax slabs/rates resulting in reduction of litigation.

5. Better Revenue Collection and Stability: The Government will receive its due tax on the final consumer/retail sale price. There will be a minimum possibility of revenue leakage, since the tax credit will be given only if the proof of tax paid at an earlier stage is produced. Another attribute of VAT is that it is an exceptionally stable and flexible source of government revenue. The stability of VAT as a revenue source stems from the fact that if consumption is less volatile the income system provides a flexible instrument of taxation, since it is collected on a current basis. The decision about revenue can also be taken correctly as variance in rate of tax has directed relation with revenue collection.

6. Exports: VAT frees exports from the burden of tax in that the tax paid on inputs can be identified and recovered by the exporter. Consequently, goods enter into international trade on an equal footing in this respect with those from other countries.

7. VAT as an Aid to Tax Reform: A full VAT paid on importations and extending throughout manufacturing, wholesale/distribution and retail businesses - and including services - provides a wide tax base and, depending on the state of the economy, a buoyant source of revenue.

8. Planning Skills: In order to produce good results, the introduction of a VAT, whether a full or partial ("credit") system, needs to be carefully planned. This requires the setting up of a team dedicated to the work and allows new skills to be developed, possibly with the assistance of consultants who have been involved in such projects in other countries.

9. Increased Administrative Capabilities: The introduction of a VAT will require the drafting of new law and new regulations. For the administration, this will involve the setting up of new organizational structures, the designing of new procedures and forms, writing of new instructions, arranging for the provision of better management information and statistics, etc. This gives the administration the opportunity to develop new skills and abilities which can subsequently be deployed right across the tax systems. A necessary feature of a VAT is the introduction of computer systems or the enhancement of those currently in operation.

10. New Relationship with Taxpayers: In some developing countries, contacts between the administration and the taxpayers are limited to routine control duties and to enforcement and audit activities. Introducing a new tax allows a fresh approach to be made. Publicity campaigns can be designed with a view to improving the taxpayer's view of officialdom. 
11. Better Record keeping by the Business Community: The control of VAT rests on the use of invoices and the keeping of records by the taxpayers. In this connection, much will depend on the level of turnover at which businesses are required to register for tax. If the level is set too low, the cost of adequate control may become excessive. Good publicity aimed at the education of taxpayers in the requirements of the tax will facilitate its administration and can lead, in time, to a general improvement in business procedures.

12. Use of Unique Numeric Identifiers: For a VAT it is essential that each business registered for the tax is identified by means of an identification unique number to that business. Where a suitable system of numbering already exists, it should be used for the VAT. Where it does not, a system of unique numbers (incorporating check digits) will have to be developed.

13. Training: An Essential Element of Progress in neglected areas in many administrations is training. Good training is expensive to design and carry into effect, but the rewards are great. Work is done better and complaints are fewer; there is greater flexibility in the use of staff whose morale and motivation are improved. As a result, costs are reduced. To introduce a new tax with any degree of success, staff at all levels must be well trained - from junior clerks to top management. This provides a further opportunity to improve on past performance. In the case of VAT, the experience is gained in such matters as reviewing and redesigning training organizations, obtaining accommodation where this is currently inadequate, obtaining modern training equipment, preparing new course material, examining and improving training methods. VAT simplifies tax administration and increases efficiency in resource allocation.

\section{Disadvantages of VAT}

Despite having the above advantages, the VAT is not free from its limitations. No matter how well efficient and effective a system is developed but it has to face its part of limitation. The disadvantages of VAT are as follows: ${ }^{\text {9]; [16] }}$

1. Price Effect of VAT on Retail Price: A persistent criticism of the VAT form has been that since the tax is payable on the final sale price, the VAT usually increases the price of the goods. However, there appears to be an intrinsic reason as to why should have any inflationary impact if it merely replaces the existing equal yield tax. It is possible that the final price under the VAT system may not be more than the price under the sales tax system. A survey of the price effect of introducing in more than 130 countries resulted in a conclusion that in more than $80 \%$ countries it did not alter the rate of inflation. It may also be pointed out that with the introduction of VAT; the tax impact of raw material is to be totally eliminated.

2. The cost of Administration to the Country: Another point which needs consideration is the question of the cost of administration to the Country. Because of the introduction of VAT, the administration cost to the country can increase significantly as the number of dealers to be administered will give up significantly. However, this increase is required to be evaluated against the likely gains under the VAT.

3. Compliance cost to the Dealers: It is argued that for compliance with the VAT provision, the accounting cost will increase. The burden of this increase may not be commensurate with the benefit to traders and small firms. Therefore, there may not be a significant increase in the cost of the goods or services.

4. Increase in Working Capital Requirement: Another possible weak point in the introduction of VAT, which will have an adverse impact on it, is that, since the tax is to be imposed or paid at various stages and not on the last stage, it would increase the working capital requirements and the interest burden on the same.

5. Regressive Opponents of the VAT argue that the VAT, like another consumption based-revenue source, is inherently regressive. Those least able to pay to face the highest overall burdens. Because it is believed that the VAT is a broad-based tax levied on essential goods and as such must be regressive.

6. Other demerits of VAT system are- The VAT needs a formal economy where all economic units from importers to retailers document their transactions and maintain accurate records. However, in developing countries, the informal economy covers substantial trading which is not documented and registered. Moreover, the low literacy rate may result in poor compliance of the VAT Act and Rules. Therefore, the VAT in such countries may fail to achieve its objectives. From the perspective of equity and justice, necessities and small units are exempted from the VAT. Although this reduces administration costs of the government and the burden of compliance on the small units. But such exemption narrows the tax base, distorts the system and hence limits its success.

\section{Conclusion}

VAT is not designed to correct inequities. It is a part of the overall tax system in the country and as such the impact of VAT should be considered in the context of the overall tax system. In fact, the tax system is not an efficient instrument for ensuring equity. In Bangladesh, VAT has been found to be moderately revenue augmenting during the first years of introduction. In terms of complexity of development, demand for human resources and the impact it will have on the society, will rank the implementation of VAT in Bangladesh as one of the most significant development projects ever undertaken in this country. The introduction of VAT in any 
country poses a gigantic management problem. The transitional issues need special attention which often spans over 3-4 years. Once the transitional phase is over, and the base is consolidated, then the benefits of the system come into full play. It is, therefore, imperative to strive hard to lay the system firmly in place, initiate related changes and integrate the same into socio-economic mosaic of the country as surely and as smoothly as possible so that the tax-induced and related distortions are removed, paving the way for industrial expansion along economically justified lines and at the same time enough revenues are generated to reduce external dependence and contribute to the building of a self-reliant Bangladesh. ${ }^{[13]}$ The success of VAT, on the other hand, crucially depends on efficient administration and developed accounting system. One need not argue about the state of accounts keeping in ordinary transactions in Bangladesh while the poor administration is the major weakness of our tax system. Thus poor tax administration and narrow tax base remain to be the crucial stumbling blocks in improving our tax revenue and elasticity of the tax structure.

As the complete implementation of VAT is costly as it is based on full billing system as well as relatively complex to understand, hence the success of this tax depends completely on the awareness of the people, otherwise tax evasion will be widespread.The introduction of VAT was the result of the global popularity of the system as a modern tax and the increasingly felt need for harmonization of the tax systems across the world. However, the single flat rate of VAT is ideally simple in nature but inconsistent with the broader policy of different treatment of different commodities for obtaining non-revenue socio-economic goals of the nation.The reform activities in Bangladesh illustrate an environmental dependency model where the changes occur in response to the political and economical environment in the context of which the tax policy makers operate. But a deeper analysis reveals a Niskanina rational model where the individual bureaucrat is assumed to be rational actor seeking to maximize personal gain and self-interest in course of day to day activities. Hence tax reform in Bangladesh appears to be mainly the product of bureaucratic politics who seeks to protect their position by minimizing the political cost of tax program while preventing a budget shortfall. Since the 1960s, more than 75 industrial and developing countries have embraced the VAT and it has become the main consumption tax across the globe. Although the specific reasons for adopting the VAT differ from one country to another, the main argument is that properly designed VAT raises more revenue with less administrative and economic cost than other broadly based taxes.

VAT does not influence the methods of doing business, it ensures neutrality in international trade by freeing exports of tax, treats import and domestic goods the same, and is much harder to evade in comparison to other consumption taxes. There can be no doubt about the significant advantages to be gained from the introduction of VAT. This is borne out by many of the studies carried out in countries which have introduced it, showing a growth in revenue yield and stimulation of the economy. If a developing country needs to review its taxation strategy, the use of a VAT as a first step should be given serious consideration. The widespread use of this tax in highly industrialized and developing nations alike indicates that it has a basic effectiveness that cannot be ignored. However, it is not a simple tax and needs care in its introduction and administration. Furthermore, an effective VAT can, in time, lead to improvements in record keeping and reporting by businesses which benefit the whole of the trading community. In introducing a VAT many countries have encountered serious difficulties due to two main causes. The first is that the basic tax structure has been made too complex, e.g. too many rates of tax, too many exemptions from tax, etc. The second is that the administration has found itself unequal to the task of making the tax operate with a reasonable degree of success. The VAT avoids most of the negative features of the sales tax and excise taxes. It removes cascading, allowing the tax content of any product to be known with a greater degree of certainty and thus leading to better resource allocation decisions as the investment decisions can be taken independently of the tax policies. The self-policing and cross checking properties of VAT as well as its collection in stages leaves less incentive for evasion. There is no frequent change in tax policies allowing investors to operate in a certain and stable tax environment. VAT simplifies tax administration and increases efficiency in resource allocation

\section{References}

[1]. $\quad$ Ebrill, Liam, et al. "The Allure of the Value-Added Tax." Finance and Development, June 2002.

[2]. "Get the VAT Out: Tax Refund." U.S. News \& World Report, 28 April 1997.

[3]. Hooper, Paul, and Karen A. Smith. "A Value-Added Tax in the U.S.: An Argument in Favor." Business Horizons, May-June 1997.

[4]. "Introduce VAT to Halt Sales Tax War Among States." Business Line, 19 May 1999.

[5]. Ogley, Adrian. Principles of Value-Added Tax-A European Perspective. International Information Services, Inc., 1998.

[6]. Ross, Graeme. "Indirect Taxation-Designing Its Future." International Tax Revenue, October 2004

[7]. Scott, Andrew. "Taxing Financial Services: A Future with Options." OECD Observer, January 1999.

[8]. "What's Wrong with the System?" U.S. News \& World Report, 18 April 1983.

[9]. Value-Added Tax - organization, levels, system, type, company, disadvantages, business, system http://www. referenceforbusiness. com/management/Tr-Z/Value-Added-Tax.html\#ixzz3RIDy6kyV

[10]. Bangladesh. "What is VAT?". National Board of Revenue. Retrieved 19 September 2016.

[11]. Syed Samiul Basher Anik (3 June 2016). "New VAT law from July 2017". Dhaka Tribune. Retrieved 19 September 2016.

[12]. Peoples' Republic of Bangladesh. "Value Added Tax Law, 1991 (Law no. 22 of 1991)". Government of Bangladesh.

[13]. Bangladesh. "What is VAT Rate in Bangladesh?". National Board of Revenue. Retrieved 19 September 2016. 
[14]. Abdur Rahim Harmachi (2016-02-21). "Bangladesh lifts VAT on computers, spares". Bdnews24.com. Retrieved 19 September 2016.

[15]. Assignmentpoint.com/business/finance/report of VAT in Bangladesh

[16]. Value Added Tax in Bangladesh, (www.nbr.gov.bd)

[17]. Importance of Value Added Tax in Bangladesh, (www.dhakatribune.com)

[18]. Cavalcanti and Li, 2000; Tanzi and Zee, 2000 OECD, 1996 and WB, 2003

[19]. Islam Rafiqul \& Bala Swapan Kumar, "Value Added Tax on Goods \& Services", (www. banglapedia.org), (This page was last modified on 5 May 2014, at 11:49,Banglapedia -). 